\title{
Voltametri Pelucutan Anodik Menggunakan Elektroda Pasta Karbon Termodifikasi Bentonit untuk Penentuan Kadar Ion Cd(II) dalam Sayur Sawi Putih
}

\author{
Irdhawati $^{*}$, Ni Kadek Nevi Titasia ${ }^{1}$, Emmy Sahara ${ }^{1}$ \\ 1Program Studi Kimia, Fakultas Matematika dan Ilmu Pengetahuan Alam, Universitas Udayana, Bali, \\ Indonesia
}

Corresponding Author:

Irdhawati

irdhawati@unud.ac.id

Received: May 2021

Accepted: August 2021

Published: September 2021

(CIrdhawati et al. This is an open-access article distributed under the terms of the Creative Commons Attribution License, which permits unrestricted use, distribution, and reproduction in any medium, provided the original author and source are credited.

\begin{abstract}
In this study, the measurement of $\mathrm{Cd}$ (II) ion by anodic stripping voltammetry technique was conducted using bentonite modified carbon paste as working electrode (CPE-B). The performance of CPE-B was compared with carbon paste electrode without bentonite (CPE) and applied for determination of $\mathrm{Cd}(\mathrm{II})$ concentration in chicory. Optimized parameters were composition of bentonite in carbon paste electrode, deposition time, deposition potential, and scan rate. Validation of measurements was observed including determination of linear concentration range, detection and quantization limits, repeatability of measurement, and percentage of recovery. The optimum composition of bentonite in CPE-B was found at $50 \%$. Furthermore, in the optimization of measurements condition was found the optimum deposition times were 90 and $60 \mathrm{~s}$, deposition potentials were -0.63 and -0.53 $\mathrm{V}$, and scan rates were 15 and $20 \mathrm{mV} / \mathrm{s}$, for CPE and CPE-B. The linear range concentration for CPE observed at 25-2000 $\mu \mathrm{g} / \mathrm{L}$ and CPE-B was 5-50 $\mu \mathrm{g} / \mathrm{L}$. Limit of detection and quantization using CPE-B were $0.337 \mu \mathrm{g} / \mathrm{L}$ and 0.349 $\mu \mathrm{g} / \mathrm{L}$, lower than CPE i.e., $0.470 \mu \mathrm{g} / \mathrm{L}$ and $0.471 \mu \mathrm{g} / \mathrm{L}$, respectively. Repeatability measurement of Cd(II) had Horwitz Ratio value less than two, and percentage of recovery was $96.73 \pm 8.33 \%$. The level of $\mathrm{Cd}(\mathrm{II})$ ion in chicory was found at $6.98 \pm 0.40 \mathrm{mg} / \mathrm{kg}$.
\end{abstract}

Keywords: anodic stripping voltammetry, Cd(II) ion, carbon paste electrode, bentonite, chicory

\section{Pendahuluan}

Pengembangan metode analisis bahan kimia sangat pesat yang bertujuan untuk memperoleh metode analisis dengan hasil yang akurat dan limit deteksi yang rendah. Voltametri merupakan salah satu metoda elektrokimia yang mengukur arus listrik sebagai fungsi potensial yang diberikan. Metoda voltametri dapat digunakan untuk menentukan konsentrasi zat organik maupun anorganik yang terdapat dalam sampel, dari terjadinya reaksi oksidasi reduksi pada permukaan elektroda. Voltametri mempunyai keunggulan yaitu memiliki sensitivitas tinggi, biaya analisis yang murah, preparasi sampel yang mudah, dan permukaan elektroda kerja dapat dimodifikasi sehingga limit deteksi dapat mencapai pada skala $\mathrm{ng} / \mathrm{L}^{[1]}$. Salah satu teknik yang dapat digunakan untuk menentukan kadar ion logam adalah anodic stripping voltammetry (ASV) atau teknik voltametri pelucutan anodik.

Dalam teknik ASV digunakan sistem tiga elektroda yaitu elektroda kerja, elektroda pembanding, dan elektroda lawan. Elektroda 
kerja yang sering digunakan yaitu elektroda pasta karbon karena harganya relatif murah, permukaan dapat diperbaharui, berpori, dan komposisi pasta karbon dapat dimodifikasi. Tujuan modifikasi elektroda kerja yaitu untuk meningkatkan kinerja dalam mendeteksi sampel dengan kadar yang sangat kecil[1]. Elektroda pasta karbon dapat dimodifikasi dengan dua cara, yaitu melapisi permukaan elektroda dengan film tipis dari modifier (surface modified), dan mencampurkan modifier sebagai salah satu bahan elektroda (bulk modified) ${ }^{[1],[2]}$. Modifier yang dapat digunakan dalam elektroda pasta karbon antara lain zeolit[3],[4] eter mahkota[5][6], ferrosen ${ }^{[7]}, \mathrm{Fe}_{2} \mathrm{O}_{3}\left[{ }^{[8][9]}\right.$, kitosan ${ }^{[10]}$, kurkumin $^{[11]}$, dan bentonit ${ }^{[12][13][14]}$. Bentonit dapat digunakan sebagai modifier dalam pasta karbon karena adanya gugus-gugus fungsi dalam bentonit yang dapat mempercepat laju transfer elektron. Bentonit diaktivasi untuk membuka pori-pori dan membersihkan dari pengotor sehingga dapat bereaksi dengan analit target dalam sampel.

Bentonit merupakan lempung dengan komposisi utama montmorillonit yang mempunyai struktur berlapis aluminosilikat dan mempunyai sifat adsorptif yang kuat. Bentonit secara luas digunakan dalam bidang elektrokimia untuk analisis senyawa organik dan anorganik karena mempunyai keunggulan antara lain ramah lingkungan, area permukaan spesifik yang luas, dan stabil secara fisik dan

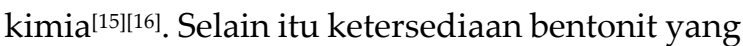
banyak di alam dan harganya murah. Dalam penelitian ini bentonit digunakan dalam pasta karbon untuk penentuan logam $\mathrm{Cd}(\mathrm{II})$ dengan teknik ASV.

Teknik ASV banyak digunakan dalam analisis dalam skala runut karena adanya proses prekonsentrasi (deposisi) dengan reaksi oksidasi ion logam dalam larutan pada permukaan elektroda. Selanjutnya terjadi reaksi reduksi untuk melepaskan (stripping) logam pada permukaan elektroda kembali ke dalam larutan. Pada saat terjadi deposisi, potensial listrik yang diberikan, waktu deposisi, dan laju pindai pengukuran sangat mempengaruhi jumlah logam yang terdeposisi pada permukaan elektroda ${ }^{[1][2],}$

Logam Cd mempunyai ciri fisik berwarna putih keperakan, tahan terhadap korosi dan panas ${ }^{[17]}$. Bentuk oksidasi dari logam kadmium adalah kadmium(II) dengan potensial reduksi standar $0.40 \mathrm{Volt}^{[2]}$. Reaksi redoks ion Cd(II) terjadi pada permukaan elektroda kerja. Logam $\mathrm{Cd}$ dapat ditemukan di alam dalam bentuk persenyawaan dengan fosfat. Logam berat kadmium sering menjadi cemaran logam di lahan pertanian karena berasosiasi dengan penggunaan pupuk fosfat. Selain itu, logam kadmium sudah terdapat di tanah terutama dari erupsi gunung berapi yang berada di dataran tinggi. Berbeda dengan logam berat lainnya yang bersifat toksik, yang bisa berasal dari pestisida atau fungisida, keberadaan logam Cd bersifat alamiah. Logam $\mathrm{Cd}$ sangat toksik terhadap makhluk hidup sehingga batas maksimal yang diperbolehkan pada sayuran berada pada level yang sangat rendah[15]. Oleh karena itu monitoring kandungan logam $\mathrm{Cd}$ dalam tanaman sangat penting dilakukan, terutama sayur-sayuran yang ditanam di dataran tinggi, diantaranya sawi putih.

Sawi putih (Brassica rapa subsp. pakinensis) ditanam pada tanah yang mengandung humus, drainase yang baik, dan subur, karena sawi putih tidak dapat tumbuh dengan baik pada air yang tergenang ${ }^{[18]}$. Tanaman sawi putih memerlukan unsur nitrogen lebih banyak untuk pembentukan klorofil serta pertumbuhan pada fase vegetatif yang berguna bagi pertumbuhan batang, cabang, dan daun ${ }^{[19]}$.

Kebaruan dari penelitian yang telah dilakukan yaitu penggunaan bentonit alam sebagai modifier dalam pasta karbon yang bertujuan untuk memanfaatkan mineral alam yang banyak terdapat di Indonesia dalam analisis logam dengan teknik ASV. Dalam penelitian ini telah dilakukan modifikasi elektroda pasta karbon menggunakan bentonit dengan cara mencampur bentonit ke dalam pasta karbon, sebelum dimasukkan ke badan elektroda kerja. Elektroda kerja yang dibuat dioptimasi dan divalidasi sebelum digunakan untuk 
menentukan kadar logam Cd dalam sampel. Parameter optimasi yang diamati yaitu komposisi bentonit dalam pasta karbon, waktu deposisi, potensial deposisi, dan laju pindai. Untuk uji validitas, dilakukan penentuan rentang konsentrasi linier, limit deteksi, limit kuantisasi, keberulangan pengukuran, dan persentase perolehan kembali. Pada kondisi pengukuran optimum, elektroda kerja digunakan untuk menentukan kadar logam $\mathrm{Cd}$ dalam sampel sayur putih. Hasil optimasi pengukuran yang diperoleh yaitu pada komposisi bentonit optimum dalam pasta karbon (EPKB) 0.6\%, waktu deposisi, potensial deposisi, dan laju pindai lebih baik dibandingkan menggunakan elektroda pasta karbon tanpa modifikasi (EPK). Demikian pula dengan hasil validasi, rentang konsentrasi linier dan kepekaan EPKB lebih baik dari EPK, dengan keberulangan dan persentase perolehan kembali yang memenuhi syarat.

\section{Metodologi Penelitian}

\section{Bahan kimia}

Bahan yang digunakan pada penelitian ini yaitu: $\mathrm{K}_{3} \mathrm{Fe}(\mathrm{CN})_{6}, \quad \mathrm{~K}_{4} \mathrm{Fe}(\mathrm{CN})_{6} .3 \mathrm{H}_{2} \mathrm{O}, \quad \mathrm{H}_{2} \mathrm{SO}_{4}$, $\mathrm{Pb}\left(\mathrm{NO}_{3}\right)_{2} .3 \mathrm{H}_{2} \mathrm{O}, \mathrm{Cu}\left(\mathrm{NO}_{3}\right)_{2} .3 \mathrm{H}_{2} \mathrm{O},\left(\mathrm{CdCl}_{2}\right)_{2} .5 \mathrm{H}_{2} \mathrm{O}$, dan aseton dari Merck, $\mathrm{KCl}$ dan aluminium slurry 0.05 dari Wako, serta bentonit alam yang berasal dari Padalarang, Jawa Barat, kertas saring lokal, kertas lakmus, akuades, dan akuabides. Bahan-bahan kimia yang digunakan memiliki kualitas pro analisis, tanpa pemurnian lebih lanjut.

\section{Peralatan}

Peralatan yang digunakan pada penelitian ini yaitu: Potensiostat Ingsens 1030, elektroda kerja pasta karbon dengan konduktor kawat $\mathrm{Cu}$ diameter $1 \mathrm{~mm}$ dalam tabung teflon, kawat $\mathrm{Ag}$ diamater $0.5 \mathrm{~mm}$ dari Nilaco dan tabung kaca dengan membran berpori G3 sebagai elektroda pembanding $\mathrm{Ag} / \mathrm{AgCl}$, kawat platina diamater $0.5 \mathrm{~mm}$ dari Nilaco sebagai elektroda lawan. Selain itu digunakan mortar agate, polishing sheet, neraca analitik Shimadzu Type ATY224, pengaduk magnetik, spatula, pipet mikro, adaptor DC, oven, metal block digester ZX, serta peralatan gelas di laboratorium.

\section{Prosedur penelitian}

\section{Optimasi komposisi bentonit}

Kawat tembaga berdiameter $1 \mathrm{~mm}$ di potong sepanjang $7 \mathrm{~cm}$ kemudian dimasukkan ke dalam tabung teflon dan diberikan sedikit ruang untuk tempat pasta karbon pada bagian bawah \pm 5 $\mathrm{mm}$. Elektroda pasta karbon (EPK) dibuat dengan mencampur $100 \mathrm{mg}$ grafit dengan $35 \mu \mathrm{L}$ paraffin cair (EPK-B), sedangkan elektroda pasta karbon termodifikasi bentonit dibuat dengan mencampur bentonit dengan komposisi 30; 35; $40 ; 45 ; 50 ; 55 \%(\mathrm{~b} / \mathrm{b})$ dari berat grafit dan $35 \mu \mathrm{L}$ paraffin cair, digerus hingga homogen dalam agate mortar. Pasta karbon dimasukkan ke badan elektroda secara manual, permukaan elektroda dihaluskan di atas kertas perkamen sampai rata dan mengkilap. Larutan uji yang digunakan adalah Cd(II) $500 \mu \mathrm{g} / \mathrm{L}$, elektroda pembanding $\mathrm{Ag} / \mathrm{AgCl}$, dan elektroda lawan Pt koil, untuk setiap komposisi bentonit pengukuran diulang sebanyak tiga kali.

\section{Optimasi waktu deposisi}

Pengukuran dilakukan dengan variasi waktu deposisi 30; 60; 90; 120; 150 detik dengan dengan kecepatan pengadukan $2000 \mathrm{rpm}$, waktu diam 25 detik, rentang potensial pengukuran dari -2.5 $\mathrm{V}$ sampai $+0.1 \mathrm{~V}$, dan laju pindai $15 \mathrm{mV} / \mathrm{s}$. Elektroda kerja yang digunakan adalah EPK dan EPK-B pada kondisi optimum.

\section{Optimasi potensial deposisi}

Variasi potensial deposisi yaitu $-0.43 ;-0.53 ;-0.63$; $-0.73 ;-0.83 \mathrm{~V}$ dengan kecepatan pengadukan 2000 rpm, waktu diam 25 detik, rentang potensial pengukuran dari $-2.5 \mathrm{~V}$ sampai $+0.1 \mathrm{~V}$, dan laju pindai $15 \mathrm{mV} / \mathrm{s}$. Waktu deposisi pengukuran disesuaikan dengan kondisi optimum yang diperoleh pada prosedur sebelumnya. Pengukuran dilakukan menggunakan elektroda kerja EPK dan EPK-B pada kondisi optimum. 


\section{Optimasi laju pindai}

Variasi laju pindai yaitu 5; 10; 15; 20; dan 25 $\mathrm{mV} / \mathrm{s}$, dengan kecepatan pengadukan $2000 \mathrm{rpm}$, waktu diam 25 detik, rentang potensial pengukuran dari $-2.5 \mathrm{~V}$ sampai $+0.1 \mathrm{~V}$. Waktu deposisi dan potensial deposisi pengukuran disesuaikan dengan data optimum yang diperoleh pada prosedur sebelumnya. Pengukuran larutan uji menggunakan elektroda kerja EPK dan EPK-B pada kondisi optimum.

\section{Validasi pengukuran}

\section{Rentang konsentrasi linier}

Rentang konsentrasi linier ditentukan dengan mengukur arus puncak larutan $\mathrm{Cd}(\mathrm{II})$ dengan konsentrasi 5 sampai $2000 \mu \mathrm{g} / \mathrm{L}$ menggunakan EPK dan EPK-B dengan tiga kali pengulangan. Arus yang terukur di sumbu y dibuat plot dengan konsentrasi larutan di sumbu x. Rentang konsentrasi linier menghasilkan persamaan garis lurus $\mathrm{y}=\mathrm{a}+\mathrm{bx}$ dengan nilai $\mathrm{R}^{2}$ mendekati 1.00 .

\section{Limit deteksi (LoD) dan limit kuantisasi (LoQ)}

LoD dan LoQ dihitung dengan Persamaan 1-4 yaitu ${ }^{[20]}$.

$$
\begin{aligned}
& \mathrm{S}_{\mathrm{y} / \mathrm{x}}=\sqrt{\frac{\sum\left(\mathrm{y}_{\mathrm{i}-} \dot{\mathrm{y}}_{\mathrm{i}}\right)^{2}}{\mathrm{n}-2}} \\
& \mathrm{~S}_{b}=\frac{\frac{S_{y}}{x}}{\sqrt{\sum\left(x_{i}-\overline{x)^{2}}\right.}} \\
& \mathrm{LoD}=\mathrm{Y}_{\mathrm{b}}+3 S_{\mathrm{b}} \\
& \mathrm{LoQ}=\mathrm{Y}_{\mathrm{b}}+10 \mathrm{~S}_{\mathrm{b}}
\end{aligned}
$$

\section{Keterangan:}

$\mathrm{S}_{\mathrm{y} / \mathrm{x}}=$ standar deviasi terhadap garis regresi

$\mathrm{S}_{\mathrm{b}}=$ standar deviasi slope/kemiringan garis

$\mathrm{Y}_{\mathrm{b}}=$ respon blanko

\section{Keberulangan pengukuran}

Pengukuran dilakukan sebanyak 10 kali pada salah satu konsentrasi ion $\mathrm{Cd}(\mathrm{II})$ yang telah didapatkan dari hasil rentang konsentrasi linier pada kondisi optimum yang diperoleh pada tahap optimasi. Selanjutnya dihitung nilai standar deviasi (SD), relative standard deviasi (RSD), dan koefisien variansi (CV). Nilai CV dibandingkan dengan $\mathrm{CV}$ Horwitz sehingga diperoleh rasio Horwitz. Keberulangan dapat diterima apabila rasio Horwitz kurang dari $2^{[21]}$.

\section{Persentase perolehan kembali}

Persentase perolehan kembali ditentukan dengan membandingkan konsentrasi larutan standar yang diukur dengan alat dan konsentrasi larutan standar yang telah diketahui. Nilai persentase perolehan kembali yang dapat diterima untuk pengukuran analit dalam satuan konsentrasi $\mu \mathrm{g} / \mathrm{L}$ berada pada rentang $80 \%$ sampai $110 \%$. Persentase perolehan kembali dapat dihitung dengan Persamaan 5:

$\% \mathrm{R}=\frac{\text { [sampel+spike]- [sampel ukur] }}{\text { [standar]hitung }} \times 100 \%$

\section{Analisis ion Cd(II) dalam sampel}

Konsentrasi Cd(II) dalam sampel ditentukan menggunakan metoda penambahan standar. Sampel sawi putih segar dicuci dengan aquades dan dikeringanginkan selama 24 jam pada suhu ruang. Sampel dipotong, ditimbang, dan dikeringkan dalam oven pengering pada suhu $80{ }^{\circ} \mathrm{C}$ hingga diperoleh massa konstan, untuk menentukan kadar air. Sampel kering dihaluskan dengan cara ditumbuk, lalu ditimbang $2 \mathrm{~g}$, dimasukkan ke dalam tabung digesti, dan didigesti dengan $20 \mathrm{~mL}$ aqua regia pada suhu $120{ }^{\circ} \mathrm{C}$ selama 1 jam sampai sampel larut menggunakan metal block digester[23]. Larutan hasil digesti disaring kemudian filtrat ditepatkan volumenya sampai $50.0 \mathrm{~mL}$ dalam labu ukur. Selanjutnya larutan hasil digesti sampel dipipet $2.0 \mathrm{~mL}$ sebanyak 6 kali dan dimasukkan ke labu ukur $10.0 \mathrm{~mL}$. Masingmasing larutan sampel ditambahkan larutan standar dengan volume dan konsentrasi tertentu sehingga diperoleh campuran larutan sampel dan standar dengan variasi konsentrasi 
sebesar 0; 5; 10; 20; 30; $40 \mu \mathrm{gg} / \mathrm{L}$ setelah diencerkan dengan $\mathrm{HNO}_{3} 0.1 \mathrm{M}$ sampai tanda batas. Setelah itu kadar ion Cd(II) ditentukan dengan teknik voltametri pelucutan anodik menggunakan EPK-B pada kondisi optimum. Pengukuran Cd(II) menggunakan EPK-B seperti pada Gambar 1.

\section{Hasil dan Diskusi}

\section{Komposisi optimum EPK-B}

Gambar 2 menunjukkan bahwa EPK komposisi $0 \%$ bentonit memberikan arus puncak yang lebih rendah dibandingkan dengan EPK-B. Arus puncak paling tinggi diperoleh pada EPK-B dengan komposisi bentonit 50\%. Pada EPK diperoleh arus puncak sebesar $0.507 \mu \mathrm{A}$, sedangkan pada EPK-B meningkat menjadi
$0.633 \mu \mathrm{A}$. Hal ini menunjukkan bahwa bentonit dapat menjadi media transfer elektron dalam reaksi redoks yang terjadi di permukaan elektroda kerja sehingga dapat meningkatkan respon arus puncak pengukuran. Setelah mencapai komposisi optimum (komposisi 50\%) selanjutnya arus puncak semakin turun dengan meningkatnya komposisi bentonit.

\section{Penentuan waktu deposisi optimum}

Pada Gambar 3 dapat diketahui waktu deposisi optimum EPK tanpa modifikasi adalah 90 detik, sedangkan menggunakan EPK-B 60 detik. Arus puncak mengalami kenaikan hingga tercapainya waktu deposisi optimum kemudian arus menurun setelah melewati waktu deposisi optimum.

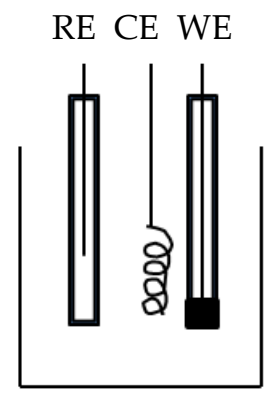

Gambar 1. Illustrasi pengukuran Cd(II) menggunakan elektroda pembanding Ag/AgCl (RE), elektroda lawan (CE), dan elektroda kerja EPK-B (WE).

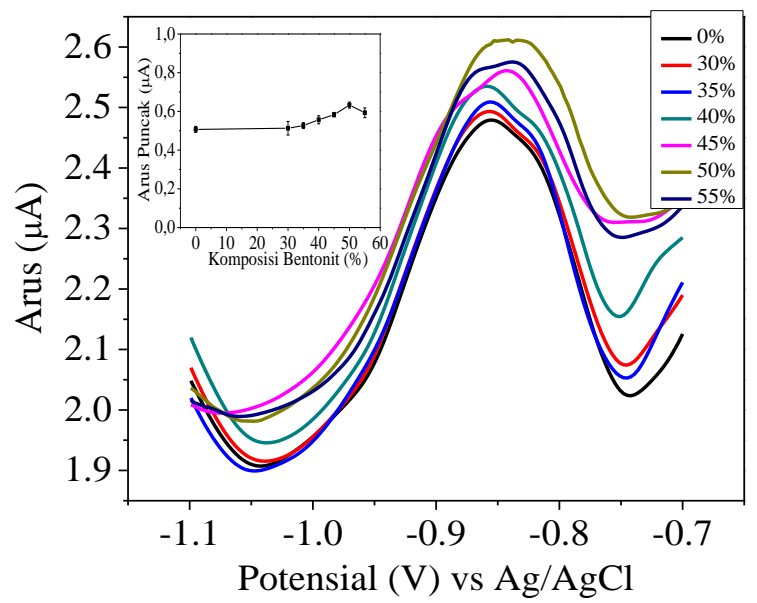

Gambar 2. Voltammogram optimasi komposisi bentonit. 

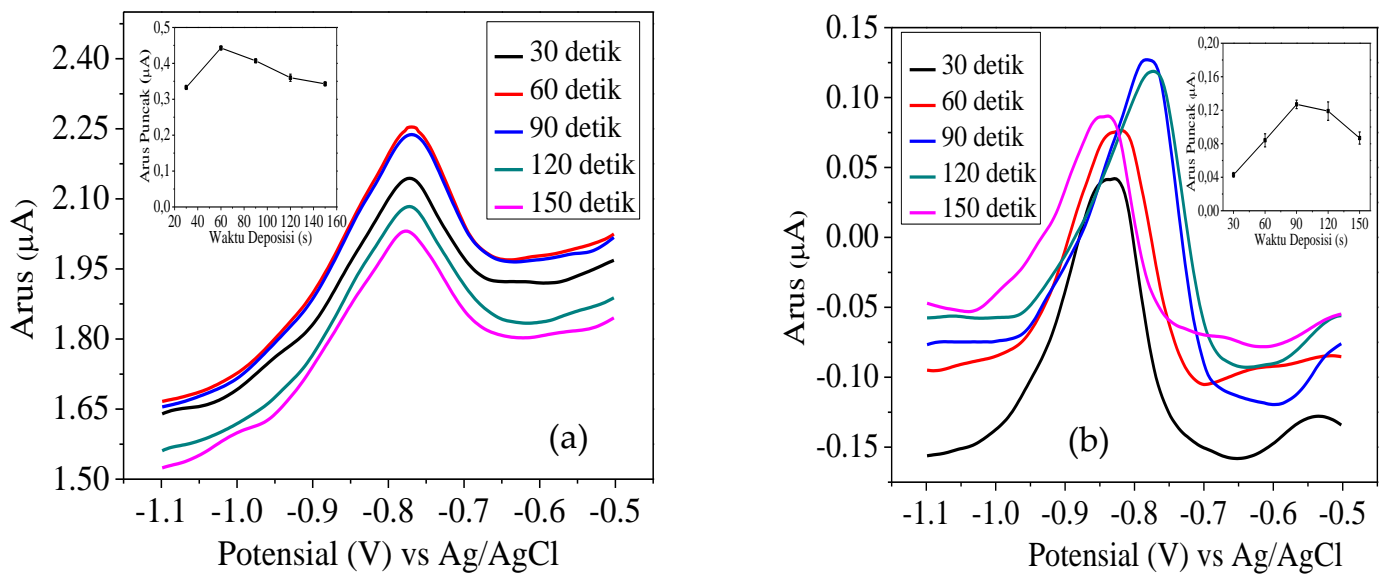

Gambar 3. Voltammogram dan plot antara waktu deposisi dengan arus puncak pengukuran menggunakan EPK (a) dan EPK-B (b).

Pada waktu deposisi optimum diperoleh arus puncak tertinggi, yang menunjukkan bahwa reaksi reduksi ion $\mathrm{Cd}(\mathrm{II})$ menjadi $\mathrm{Cd}$ pada permukaan elektroda telah mencapai kesetimbangan. Arus puncak yang dihasilkan EPK tanpa modifikasi sebesar $0.127 \mu \mathrm{A}$ pada potensial puncak $-0.779 \mathrm{~V}$ (Gambar 3a), sedangkan menggunakan EPK-B arus meningkat menjadi $0.443 \mu \mathrm{A}$ pada potensial puncak -0.768 V (Gambar 3b). Pada EPK-B diperoleh arus puncak yang lebih tinggi dibandingkan EPK karena adanya bentonit dalam pasta karbon yang mempercepat transfer elektron sehingga kesetimbangan reaksi juga lebih cepat dicapai.

\section{Optimasi potensial deposisi}

Hasil penentuan potensial deposisi optimum menunjukkan potensial deposisi menggunakan EPK diperoleh pada potensial $-0.63 \mathrm{~V}$, sedangkan menggunakan EPK-B pada potensial -0.53 V. Nilai kedua potensial tersebut lebih kecil dari potensial reduksi standar $\left(\mathrm{E}^{0}\right) \mathrm{Cd}(\mathrm{II}) / \mathrm{Cd}$ yaitu $-0.40 \mathrm{~V}$, yang berarti ion $\mathrm{Cd}(\mathrm{II})$ tereduksi sempurna menjadi $\mathrm{Cd}$, dan terdeposisi pada permukaan elektroda kerja. Arus puncak yang dihasilkan EPK yaitu $0.476 \mu \mathrm{A}$, sedangkan menggunakan EPK-B arus meningkat menjadi $0.753 \mu \mathrm{A}$. Hal ini membuktikan bahwa pada potensial deposisi optimum, adanya bentonit dalam pasta karbon meningkatkan sensitivitas pengukuran. Hasil optimasi potensial deposisi terdapat pada Gambar 4.

\section{Optimasi laju pindai}

Dari voltammogram pada Gambar 5 diperoleh nilai laju pindai menggunakan elektroda kerja EPK sebesar $15 \mathrm{mV} / \mathrm{s}$, sedangkan menggunakan EPK-B laju pindai meningkat menjadi $20 \mathrm{mV} / \mathrm{s}$. Semakin kecil laju pindai, maka arus puncak yang dihasilkan semakin rendah. Hal ini disebabkan lapisan difusi menjadi tebal sehingga transfer elektron di permukaan elektroda kerja menjadi terhambat. Arus puncak yang dihasilkan EPK yaitu $0.479 \mu \mathrm{A}$, sedangkan menggunakan EPK-B arus meningkat menjadi $0.640 \mu \mathrm{A}$. Adanya peningkatan laju pindai dan respon arus puncak pada elektroda EPK-B menunjukkan bentonit dapat mempercepat laju transfer elektron dan menambah kepekaan pengukuran. 

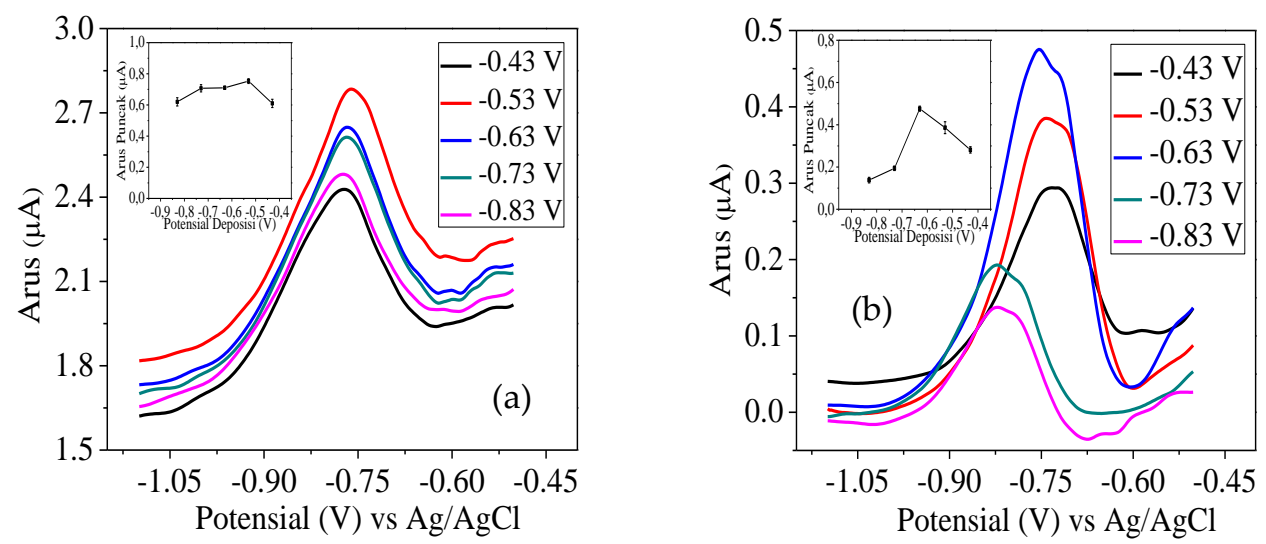

Gambar 4. Voltammogram dan plot antara potensial deposisi dengan arus puncak pengukuran menggunakan EPK (a) dan EPK-B (b).
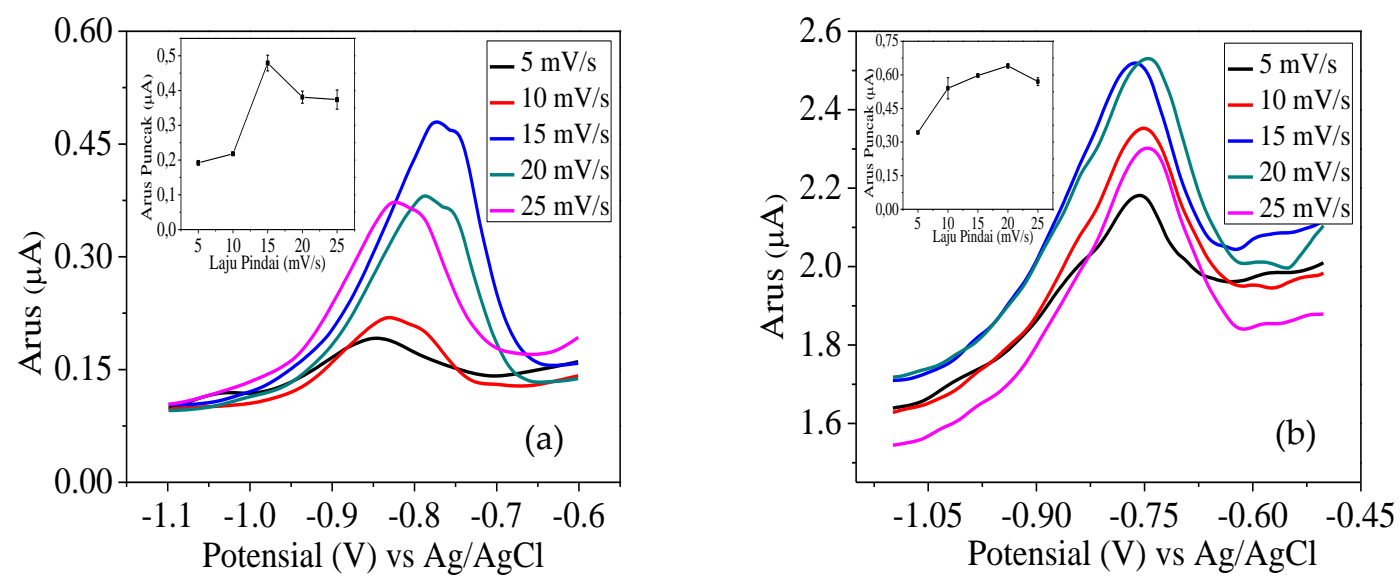

Gambar 5. Voltamogram dan plot antara laju pindai dengan arus puncak pengukuran menggunakan EPK (a) dan EPK-B (b).

\section{Validasi pengukuran}

\section{Rentang konsentrasi linier}

Penentuan rentang konsentrasi linier bertujuan untuk mengetahui rentang konsentrasi yang memberikan hubungan linier antara sinyal instrument dengan konsentrasi analit. Pengukuran rentang konsentrasi linier dilakukan pada rentang 5-2000 $\mu \mathrm{g} / \mathrm{L}$ menggunakan EPK dan EPK-B. Gambar 6 menunjukkan linearitas pengukuran ion logam
Cd(II) diperoleh pada rentang 25-1500 $\mu \mathrm{g} / \mathrm{L}$ dengan EPK tanpa modifikasi dan 5-50 $\mu \mathrm{g} / \mathrm{L}$ menggunakan EPK-B dengan nilai $\mathrm{r}^{2}$ yaitu masing-masing 0.99264 dan 0.99845 . Linieritas menggunakan elektroda kerja EPK-B dimulai pada konsentrasi yang lebih rendah yaitu 5 $\mu \mathrm{g} / \mathrm{L}$, dibandingkan EPK dari $25 \mu \mathrm{g} / \mathrm{L}$, yang menunjukkan bahwa EPK-B dapat digunakan untuk mengukur ion $\mathrm{Cd}$ (II) pada konsentrasi yang lebih kecil. Makin kecil konsentrasi awal linearitas, makin rendah limit deteksi. 

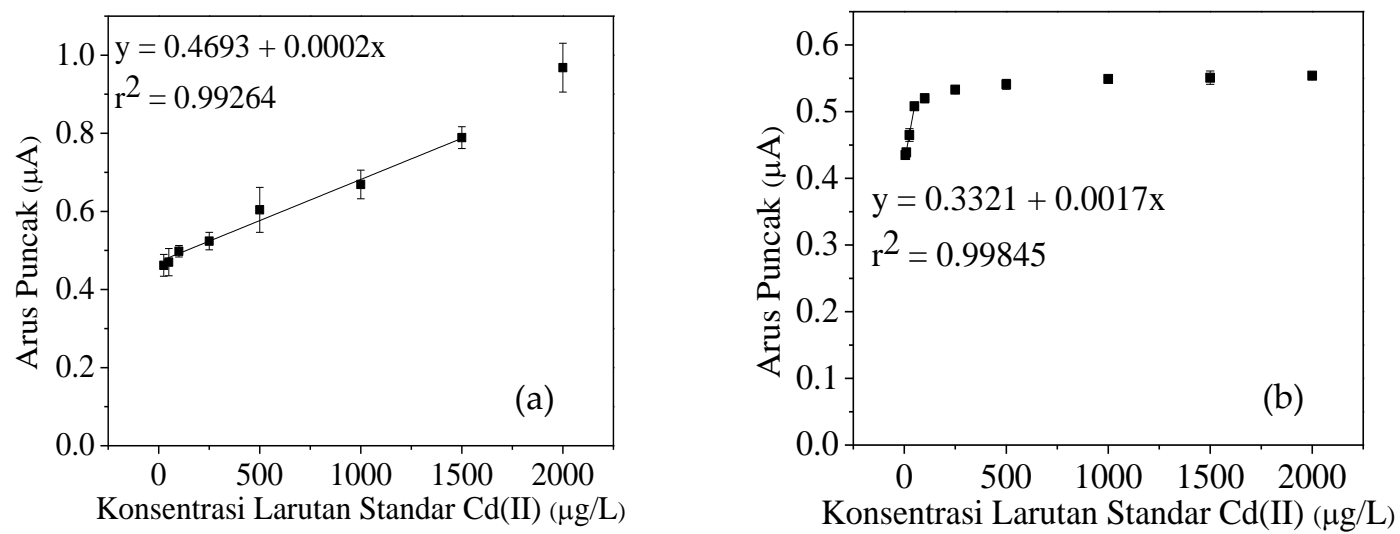

Gambar 6. (Kurva kalibrasi pengukuran larutan standar Cd(II).

\section{Limit deteksi (LoD) dan limit kuantisasi (LoQ)}

Hasil perhitungan LoD dan LoQ untuk pengukuran ion logam Cd(II) dengan EPK tanpa modifikasi sebesar $0.4699 \mu \mathrm{g} / \mathrm{L}$ dan $0.4714 \mu \mathrm{g} / \mathrm{L}$. Jika menggunakan EPK-B nilai LoD dan LoQ menurun menjadi $0.3370 \mu \mathrm{g} / \mathrm{L}$ dan $0.3487 \mu \mathrm{g} / \mathrm{L}$. Demikian pula nilai kemiringan garis (b) yang menunjukkan kepekaan pengukuran. Nilai $b$ untuk EPK-B yaitu 0.0017 lebih besar dari EPK yaitu 0.0002, sehingga dapat dinyatakan bahwa pengukuran menggunakan EPK-B lebih sensitif dibandingkan EPK. Bentonit dalam pasta karbon dapat menurunkan limit deteksi dan limit kuantisasi pengukuran.

\section{Keberulangan pengukuran}

Dalam penentuan keberulangan digunakan standar Cd(II) $50 \mu \mathrm{g} / \mathrm{L}$ sebagai larutan uji. Elektroda kerja yang digunakan adalah gabungan dari batch yang sama dan berbeda, dan pengukuran dilakukan pada hari yang sama dan berbeda. Nilai rasio Horwitz untuk ion logam $\mathrm{Cd}(\mathrm{II})$ menggunakan EPK sebesar 0.40 sedangkan menggunakan EPK-B sebesar 0.20. Gambar 7 menunjukkan arus puncak keberulangan pengukuran ion logam $\mathrm{Cd}(\mathrm{II})$, dengan arus puncak menggunakan EPKB lebih tinggi dibandingkan EPK. Menurut Horwitz dan Albert (2006) hasil pengukuran keberulangan yang baik yaitu memiliki nilai rasio Horwitz kurang dari 2. Oleh karena itu pengukuran larutan ion logam $\mathrm{Cd}(\mathrm{II})$ menggunakan EPK dan EPKB telah memenuhi syarat dan dapat diterima.

\section{Persentase perolehan kembali}

Persentase perolehan kembali ditentukan bertujuan untuk mengukur ketepatan hasil analisis. Nilai persentase perolehan kembali dari larutan standar Cd(II) $50 \mu \mathrm{g} / \mathrm{L}$ sebesar $(96.73 \pm$ 8.33)\%. Menurut AOAC (1998), nilai persentase perolehan kembali yang dapat diterima dalam satuan $\mu \mathrm{g} / \mathrm{L}$ berada pada rentang $80 \%$ sampai $110 \%$, maka persentase perolehan kembali larutan ion logam Cd(II) menggunakan EPK-B dengan teknik voltametri pelucutan anodik telah memenuhi syarat dan dapat diterima.

\section{Kadar ion Cd(II) dalam sampel sawi putih}

Kadar air dalam sampel sawi putih sebesar 91.73 $\pm 0.72 \%$. Pada Gambar 8 menunjukkan voltamogram dan kurva kalibrasi penambahan standar penentuan kadar ion Cd(II) dalam sayur sawi putih dengan persamaan garis regresi linier $\mathrm{y}=0.5194+0.0104 x$ dan $\mathrm{r}^{2}=0.98476$. Hasil yang diperoleh yaitu sebesar $6.98 \pm 0.40 \mathrm{mg} / \mathrm{kg}$. 


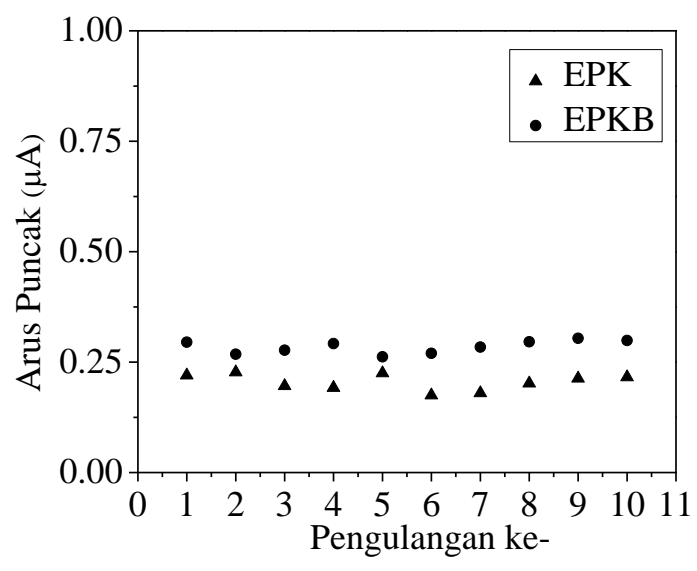

Gambar 7. Uji keberulangan pengukuran larutan standar ion Cd(II) dengan EPK dan EPK-B.

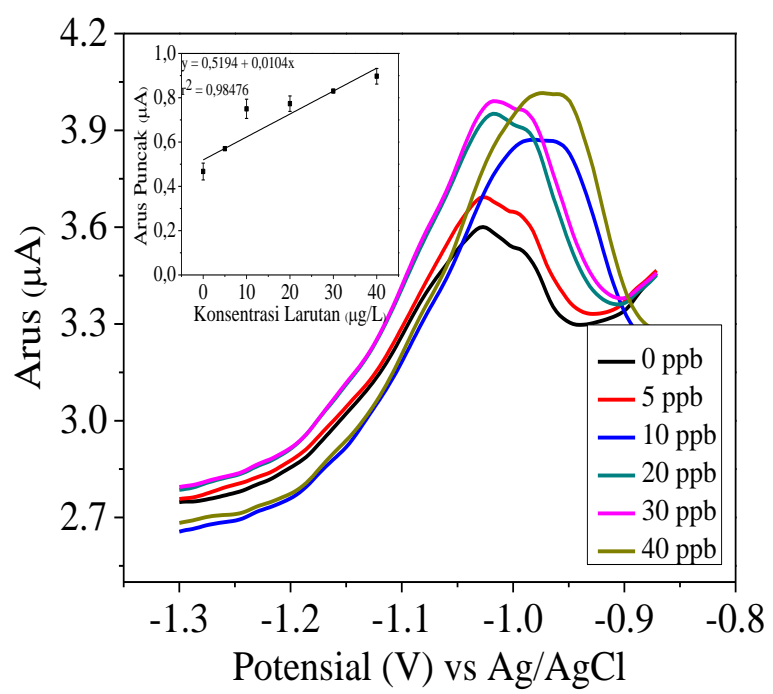

Gambar 8. Voltamogram dan plot antara konsentrasi larutan standar Cd(II) dengan arus puncak pengukuran menggunakan EPK-B.

Kadar ion Cd(II) dalam sampel tersebut telah melampaui ambang batas yang diperbolehkan sesuai dengan peraturan Badan Standardisasi Nasional Tahun 2009 tentang Batas Maksimum Cemaran Logam Berat dalam Pangan yaitu 0.2 $\mathrm{mg} / \mathrm{kg}$ untuk logam Cd${ }^{[24]}$. Cemaran logam $\mathrm{Cd}$ kemungkinan disebabkan oleh tercemarnya tanah tempat sayuran sawi putih ditanam

\section{Kesimpulan}

Adanya bentonit teraktivasi asam sebagai modifier dalam pasta karbon dapat memberikan arus puncak yang lebih tinggi dibandingkan EPK tanpa modifikasi. EPK-B komposisi 50\% dapat mengukur kadar ion Cd(II) pada konsentrasi yang lebih kecil dibandingkan EPK tanpa modifier. Hasil validasi EPK dan EPK-B diperoleh nilai LoD dan LoQ yang lebih rendah pada EPK-B, nilai keberulangan pengukuran yang lebih kecil dari dua, dan persentase perolehan kembali yang berada pada rentang $80-110 \%$. Kadar ion logam Cd(II) dalam sampel sawi putih berada di atas ambang batas yang telah ditentukan. 


\section{Ucapan Terima Kasih}

Penulis mengucapkan terima kasih kepada semua anggota grup penelitian elektrokimia, Program Studi Kimia FMIPA Universitas Udayana, atas bantuan dan kerjasamanya.

\section{Daftar Pustaka}

1. Wang, J., Analytical Electrochemistry. John Wiley \& Sons, Inc., (2001).

2. Harvey, D., Modern Analytical Chemistry. McGraw-Hill, (2000).

3. Irdhawati, I., Suyanto, H. \& Andani, P. Y., Penggunaan elektroda pasta karbon termodifikasi zeolit untuk analisis logam $\mathrm{Cu}$ secara voltametri pelucutan anodik. ALCHEMY J. Penelit. Kim., 13(1): 1-16 (2017).

4. Ahmadpour-Mobarakeh, L. \& Nezamzadeh-Ejhieh, A., A zeolite modified carbon paste electrode as useful sensor for voltammetric determination of acetaminophen. Mater. Sci. Eng. C, 49: 493499 (2015).

5. Irdhawati, I., Manurung, M. \& Maulinasari, A., Modifikasi elektroda pasta karbon dengan eter mahkota (dibenzo-18-crown-6) untuk analisis asam askorbat secara voltametri pulsa diferensial. ALCHEMY J. Penelit. Kim., 11(2): 175-191 (2015).

6. Gadhari, N. S., Sanghavi, B. J. \& Srivastava, A. K., Potentiometric stripping analysis of antimony based on carbon paste electrode modified with hexathia crown ether and rice husk. Anal. Chim. Acta, 703(1): 31-40 (2011).

7. González, J., Soto, C. M. \& Molina, A., Square Wave Voltammetry and Voltcoulometry applied to electrocatalytic reactions. Oxidation of ferrocyanide at a ferrocene modified gold electrode. J. Electroanal. Chem., 634(2): 90-97 (2009).

8. Vinay, M. M. \& Arthoba Nayaka, Y., Iron oxide (Fe2O3) nanoparticles modified carbon paste electrode as an advanced material for electrochemical investigation of paracetamol and dopamine. J. Sci. Adv.
Mater. Devices, 4(3): 442-450 (2019).

9. Alizadeh, T. \& Zargr, F., Highly selective and sensitive iodide sensor based on carbon paste electrode modified with nanosized sulfate-doped $\alpha$-Fe2O3. Mater. Chem. Phys., 240: 122118 (2020).

10. Janegitz, B. C., Marcolino-Junior, L. H., Campana-Filho, S. P., Faria, R. C. \& Fatibello-Filho, O., Anodic stripping voltammetric determination of copper(II) using a functionalized carbon nanotubes paste electrode modified with crosslinked chitosan. Sensors Actuators, B Chem., 142(1): 260-266 (2009).

11. Ojani, R., Raoof, J.-B. \& Zamani, S., A novel voltammetric sensor for amoxicillin based on nickel-curcumin complex modified carbon paste electrode. Bioelectrochemistry, 85: 44-49 (2012).

12. Alves, T. S., Santos, J. S., Fiorucci, A. R. \& Arruda, G. J., A new simple electrochemical method for the determination of Bisphenol A using bentonite as modifier. Mater. Sci. Eng. C, 105: 110048 (2019).

13. Rezaei, B., Ghiaci, M. \& Sedaghat, M. E., A selective modified bentonite-porphyrin carbon paste electrode for determination of $\mathrm{Mn}(\mathrm{II})$ by using anodic stripping voltammetry. Sensors Actuators, B Chem., 131(2): 439-447 (2008).

14. Irdhawati, I., Mawarni, E. I. I., Wijana, A. J. Y. A., Sitio, F. S., Saraswati, N. P. G. W. \& Sahara, E., Activated bentonite modifiedcarbon paste electrode for determination the level of copper ion (Cu2+) in tomato. Aceh Int. J. Sci. Technol., 9(3): 177-186 (2020).

15. Gates, W. P., Bouazza, A. \& Jock Churchman, G., Bentonite clay keeps pollutants at bay. Elements, 5(2): 105-110 (2009).

16. Koutsopoulou, E., Papoulis, D., TsolisKatagas, P. \& Kornaros, M., Clay minerals used in sanitary landfills for the retention of organic and inorganic pollutants. Appl. Clay Sci., 49(4): 372-382 (2010).

17. Vogel, A. I., Textbook of macro and semimicro qualitative inorganis analysis. Longman London, (1979). 
18. Susana, R. \& Suswati, D., Ketersediaan Cd, gejala toksisitas dan pertumbuhan 3 spesies Brassicaceae pada media gambut yang dikontaminasi kadmium (Cd). Perkeb. dan Lahan Trop., 1(2): 9-16 (2011).

19. Haryanto, E., Suhartini, T., Rahayu, E. \& Sunarjono, H., Sawi dan Selada. Penebar Swadaya, (2003).

20. Miller, J. \& Miller, J. C., Statistics and chemometrics for analytical chemistry. Pearson Education, (2005).

21. Horwitz, W. \& Albert, R., The Horwitz ratio (HorRat): A useful index of method performance with respect to precision. J.
AOAC Int., 89(4): 1095-1109 (2006).

22. AOAC., Peer verified methods program, manual on policies and procedures. 926940 (1993).

23. Irdhawati, I., Manuruang, M. \& ReicheltBrushett, A., Trace metals and nutrients in lake sediments in the Province of Bali, Indonesia: a baseline assessment linking potential sources. Mar. Freshw. Res., 72(1): 44-57 (2020).

24. Badan Standardisasi Nasional., Batas maksimum cemaran logam berat dalam pangan. 7387 (2009). 